Boylu, E. ve Çal, P. (2018). Suriyeli mültecilerin Türkçe kursuna başlamadan önceki söz varlığı durumları. Ana Dili Eğitimi Dergisi, 6(1), 68-94.

$\begin{gathered}\text { Ana Dili Eğitimi Dergisi } \\ \text { Journal of Mother Tongue Education } \\ \text { www.anadiliegitimi.com }\end{gathered}$
Geliş/Received: 14.10 .2017 Kabul/Accepted:23.12.2017

\title{
Suriyeli Mültecilerin Türkçe Kursuna Başlamadan Önceki Söz Varlığı Durumları
}

\begin{abstract}
Emrah BOYLU*
Pınar ÇAL ${ }^{* *}$

Öz

Araştırmanın amacı, Suriyeli mültecilerin Türkçe öğrenmeye başlamadan önceki Türkçe söz varlıklarını tespit etmektir. Araştırmanın çalışma grubunu i̇stanbul Aydın Üniversitesinde Türkçe öğrenmeye başlayacak olan 49'u kadın 41'i erkek olmak üzere toplam 90 öğrenci oluşturmuştur. Çalışmada amaçlı örnekleme yöntemlerinden kolay ulaşılabilir durum örneklemesi kullanılmıştır. Araştırmada elde edilen bulgulara göre Türkçe kursuna gitmeden sosyal ortamda Türkçe öğrenen kadınların toplamda 4931, erkeklerin ise 3974 Türkçe kelime bilgisine sahip oldukları ortaya çıkmıştır. Cinsiyet ayırmaksızın bilinen toplam kelime sayısı ise 8905 olarak tespit edilmiştir. Bu kapsamda Suriyeli gençlerin A1 seviyesinde Diller İçin Avrupa Ortak Önerileri Çerçevesi kapsamında kendini ve ailesini tanıtabilecek, nereli olduğunu, adresini, telefon numarasını, ne zaman nerede doğduğunu söyleyebilecek, yerine ve zamanına göre temel kalıp ifadeleri kullanabilecek kapasitede kelime bilgisine sahip olduğu görüşüne varılmıştır. Bu araştırma, Suriyeli mültecilere Türkçe eğitimi verilirken hedef kitlenin özelliklerinin özellikle kelime dağarcı̆̆ı yönünden ortaya konulması bakımından önemlidir.
\end{abstract}

Anahtar Kelimeler: Suriyeli mülteciler, Türkçe öğretimi, söz varlığı

\section{The Turkish Vocabulary Range of Syrian Refugees before They Start Turkish Courses}

\begin{abstract}
The purpose of this research was to determine the Turkish vocabulary range of Syrian refugees before they started learning Turkish. The research study group consisted of 90 students - 49 female and 41 male - who were about to start learning Turkish at Istanbul Aydın University. In this study, convenience sampling which is one of the purposeful sampling methods was used. According to the findings of the study, before attending a Turkish course, of the participants who had learned Turkish through social encounters, the women had a vocabulary range of 4931 words and the men had a vocabulary range of 3974 words. The total vocabulary size of the group, disregarding male and female distinction, was considered to be 8905. Based upon this, it was inferred that in their current state those young Syrians had already possessed the vocabulary to introduce themselves and their families, talk about where they were from, their addresses, phone numbers, when and where they were born, and also had the vocabulary range to use some basic phrases in the right place and at the right time at the $\mathrm{A} 1$ level of the Common European Framework of Reference for Languages. This
\end{abstract}

* Öğr. Gör. İstanbul Aydın Üniversitesi, Türkçe Öğretmenliği, emrahboylu@aydin.edu.tr

* * Okt. İstanbul Aydın Üniversitesi, Aydın TÖMER, pinarcal@aydin.edu.tr 
research is important in terms of determining the characteristics of the target group, especially, in terms of vocabulary while Turkish education is given to Syrian refugees.

Keywords: Syrian refugees, Turkish education, vocabulary

\section{Giriş}

Dil öğretim sürecinde dil öğrenenlerin dil becerilerini etkili bir şekilde kullanabilmeleri sahip oldukları söz varlığı ile doğru orantılıdır. Bu kapsamda dil öğretiminin en önemli amaçlarından biri de dil öğrenenlerin söz varlığını geliştirmek ve buna bağlı olarak da hedef dili doğru ve etkili kullanmalarını sağlayabilmektir. Bu çerçevede söz varlığı, TDK'da “Bir dildeki sözlerin bütünü, söz hazinesi, söz dağarcığı, sözcük hazinesi, kelime hazinesi, kelime kadrosu, vokabüler" olarak açıklanmıştır (TDK, 2017). Bu tanım doğrultusunda söz varlığı, bir dilin yüzyıllar boyunca biriktirdiği anlam yüklü seslerden oluşan bir hazine olarak açıklanabilir. Bu tanımlardan hareketle söz varlığı ile dil ilişkisinin ne denli kuvvetli olduğu anlaşılmaktadır. Öyleki Aksan söz varlığının, o dilin tarihine geniş ölçüde ışık tutmakta olduğunu, yüzyıllar boyunca ortaya çıkan ses, biçim, sözdizimi ve anlam değişikliklerini yansıttı̆̆ını, hangi dillerin etkisiyle, ne türden değişimlerin gerçekleştiğini gösterdiğini belirtir (Aksan, 2006: 11). Bu nedenle söz varlığı, hem ana dili hem de yabancı dil öğretiminde üzerinde önemle durulması gereken bir konudur. Bu doğrultuda Aksan (2000:20) okumaya yeni başlayan ilkokulun ilk sınıflarındaki öğrencilere ya da bir yabancı dili öğrenmeye başlayanlara ilk aşamada öğretilmesi gereken sözcüklerin hangileri olduğu, dilin sözcüklerinin hangi sıraya göre tanıtılması gerektiği saptanırken, değişik gereksinimleri karşılayan ana dil ve yabancı dil sözlükleri hazırlanırken dildeki ögelerin sıklıklarının bilinmesi gerektiğini vurgular. Buna ek olarak Barın (2003: 311) da yabancı dil öğretiminde temel söz varlığını belirlerken öncelikle, organ ve akrabalık adlarının, sayıların, günlük hayatta sıkça kullanılan isim ve fiiller ile onlarla ilişkisi olan kelimelerin, sıkça kullanılan deyimler, atasözleri ve iletişimde önemli bir yeri olan kalıplaşmış sözlerin ele alınması gerektiğinin altını çizer. Bu görüşlerden hareketle hem ana dili hem de yabancı dil öğretiminde söz varlığının bilinmesinin dil öğretiminin en önemli hususlarından biri olduğu söylenebilir. Fakat ana dili olarak Türkçe öğretiminde öğrencilerin söz varlığı ile ilgili (Kurudayıoğlu, 2005; Karadağ, 2005; Cesur, 2005; Çıplak, 2005; Tüysüz, 2007; Karahan, 2007; Pilav 20008; Serarslan, 2010; İpek Eğilmez, 2010; Tülü, 2012; Ceylan, 2013; Uluçay ve Börekçi, 2015; Demirci ve Baş, 2016; Takıl, 2016; Dağ, 2017 ) birçok çalışma yapılmışken yabancı dil olarak Türkçeyi öğrenenlerin söz varlıkları ile ilgili çalışma sayısının çok az olduğu, yapılan çalışmaların genel olarak ders kitaplarındaki söz varlığını tespit etmek veya karşılaştırmak, (Şimşek, 2015; Açık 2013; Arslan 2014; Büyükikiz ve Hasırcı, 2013; Çelik, 2014; Göçen ve Okur, 2016; Aşık, 2007) amacıyla yapıldığı görülmektedir. Bu bilgiler çerçevesinde yabancılara Türkçe öğretiminde temel, orta ve yüksek seviyede söz varlı̆̆ının tam olarak belirlenemediği söylenebilir. Yabancılara Türkçe 


\section{Suriyeli Mültecilerin Türkçe Kursuna Başlamadan Önceki Söz Varlığı Durumları}

öğretiminde söz varlığı ile ilgili çalışmalara bakıldığında Çelik (2014) yüksek lisans tezinde yabancı dil olarak Almanca ve yabancı dil olarak Türkçe için hazırlanmış ders kitaplarının A1 ve A2 seviyesinde kullanılan söz varlığı arasında bir ilişki olup olmadığını incelemiştir. Yabancı dil olarak Almanca öğretimi için Goethe Enstitüsünde kullanılan Netzwerk Serisi, yabancı dil olarak Türkçe öğretimi için Yunus Emre Enstitüsünde kullanılan Hitit Serisi seçilen araştırmada, ders kitaplarında seçilen kitaplar benzerlik göstermiş ise de kullanılan kelimeler ve sıklıkları arasında anlamlı bir farklılık tespit edilmiştir. Göçen ve Okur (2016) ise Gazi, Yeni Hitit ve İstanbul yabancılara Türkçe öğretimi ders kitapları setlerini incelemişlerdir. İncelenen setler sonucunda yabancılara Türkçe öğretiminde kullanılan kelime sıklıklarının ve yaygınlıklarının kitaplar arasında ortak olmadığı tespit edilmiştir. Arslan (2014) çalışmasında, Yeni Hitit Yabancılar İçin Türkçe Seti'ni kullanarak yabancılara Türkçe öğretimi için hazırlanan ders kitaplarında yer alan okuma metinlerinin söz varlığını deyimler, atasözleri, ikilemeler, ünlemler, ilişki sözleri ve özel isimleri temel alarak değerlendirmiştir. Araştırmada kelime sıklığı ve söz varlığı açısından set içinde en kapsamlı olan kitap "Yeni Hitit Yabancılar İçin Türkçe Ders Kitabı 2" olarak tespit edilmiştir. İncelenen tüm setin söz varlığı unsurları açısından deyimler haricinde zengin olmadığı saptanmıştır. Göçen (2016) doktora çalışmasında öğrencilerin yazılı anlatımlarında yer alan sözcüklerin yaygınlığını ve dil seviyelerine dağılımını A1 seviyesinin başından C1 seviyesinin sonuna kadar Türkçe öğrenen 25 öğrenci ile incelemiştir. Bu bakımdan ilgili çalışma alanda bu yönüyle oldukça önemlidir. Araştırmada, hangi söz varlığı ögelerinin, hangi seviyede, ne kadar öğretileceği konusunda yabancılar için Türkçe ders kitaplarında ortak bir kabulün olmadığı, ders kitaplarında kullanılan söz varlığı ögelerinin A1 seviyesinden C1 seviyesi ders kitabına doğru dağılımında yalnızca bir dil öğretim setinde düzenli bir ilerleme olduğu, sadece bir Türkçe öğretim setiyle öğretimin sonunda sunulan toplam söz varlığı ögesinin sayısının, Türkçe öğretim setleri arasında farklııı gösterdiği bulunmuştur. İlgili araştırmalar ışığında Türkçenin yabancı dil olarak öğretiminde söz varlığı çalışmalarının yapılmasının elzem olduğu görülmektedir.

Demokrasi ve reform hareketleri istemiyle Mart 2011'de Suriye'de baş gösteren kargaşa yerini savaşa bırakmış ve Suriye'den Türkiye'ye göçler başlamıştır. Bu kapsamda Türkiye'de 2011'den bu yana barınan mülteci sayısı 3.079.914 olarak tespit edilmiştir. Bu nüfusun \%53.2'sini Suriyeli erkekler, \%48.8'ini Suriyeli kadınlar oluşturmaktadır. Eğitim çağındaki 5 ila 17 yaş aralığındaki çocuk nüfus ise \%31'dir. (UNHCR, 2017). İlgili rakamlar dikkate alındığında 5 ila 17 yaş aralığında olup Türkiye'de yaşayan yaklaşık 1 Milyon Suriyeli mültecinin olduğu görülmektedir. Bu kapsamda Türkçeyi yabancı dil olarak öğrenenlere bu kitle de doğal olarak eklenmiştir. Fakat bu kitlenin Türkçeyi yabancı dil olarak öğrenen diğer kitlelere göre farklılıkları bulunmaktadır. Bu bağlamda en büyük farklılık ise ilgili mültecilerin belirli bir süreden beri (3-6-9 ay veya 1-3-5 yıl) Türkiye'de yaşamalarıdır. Bu nedenle ilgili öğrenciler herhangi 
bir kursa gitmeden zamanla Türkçe öğrenebilmektelerdir. Ilgili hedef kitle ile yurt dışından Türkiye’ye gelip TÖMER'lerde Türkçe öğreneceklerin Türkçe öğrenmeye başlamadan önceki söz varlıklarının aynı olduğu söylenemez. Bu gerekçe bağlamında ele alınan bu çalışmanın amacı; Türkiye'de yaşadıkları sürede herhangi bir Türkçe eğitim almamış Suriyeli mültecilerin Türkçe öğrenmeye başlamadan önceki Türkçe söz varlıklarını tespit etmektir. Bu amaç doğrultusunda araştırmanın alt problemleri şöyledir:

Suriyeli mültecilerin;

1. Türkçe söz varlığı durumları ne düzeydedir?

2. Cinsiyetlerine göre bilinen kategorileşmiş söz varlı̆̆ı durumları ne düzeydedir?

3. Türkiye'de yaşadıkları yıllara göre söz varlığı durumları ne düzeydedir?

4. Bildikleri tekrarsız kelime sayıları ne düzeydedir?

5. En çok tekrar ettiği kelimeler nelerdir?

6. Söz varlığı durumlarının temalara göre dağılımı nasıldır?

7. Kalıp sözlere yönelik söz varlığı ne düzeydedir?

\section{Yöntem}

\section{Araştırma Modeli}

İlgili alan yazına bakıldığında söz varlığı çalışmaları Baş (2011) tarafından genel amaçla yapılan söz varlığı araştırmaları, özel amaçla yapılan söz varlığı araştırmaları ve diğer söz varlığı araştırmaları olmak üzere üçe ayırmaktadır. Bu doğrultuda Keklik (2016) de eğitimle ilgili söz varlığı çalışmalarını, öğrencilerin yazılı anlatımlarında kullandığı söz varlığını araştıran çalışmalar, öğrencilerin konuşma diliyle ilgili söz varlığını araştıran çalışmalar ve yazılı belgelerle (okuma kitapları, ders kitapları, dergiler vb.) ilgili söz varlığı çalışmaları olmak üzere üçe ayırır. Bu bilgiler çerçevesinde ilgili çalışma da "yazılı anlatımlarında kullandığı söz varlığını araştıran çalışma" olarak düşünülmüş fakat ilgili öğrenciler herhangi bir Türkçe eğitim almadıkları için kendilerine verilen konu hakkında herhangi bir yazı yazamamışlardır. Bu kapsamda öğrencilerden Türkiye'de bulundukları süre içinde öğrendikleri kelimeleri (akıllarına gelen her kelimeyi) yazmaları istenmiştir ve veriler bu şekilde toplanmıştır. Veriler analiz edilirken ilgili literatürde kelime kavramında bir ortaklık olmadığı görülmüştür. Bu kapsamda Kurudayıoğlu ve Karadağ, (2005:305) Türkçe kelime hazinesi araştırmalarında kelime sınırları ile ilgili herhangi bir standardın olmadığını ve bu nedenle uygun görülen kelime tanımına göre kelime sınırlarının belirlendiğini belirtir. Bu nedenle Karadağ (2005), Kurudayıoğlu (2005), Baş (2006), Pilav (2008) ve İpek Eğilmez (2010)'in doktora çalışmalarında ayrı yazılan birleşik kelimeleri, özel isimleri, sayıları, tarihleri kelime kabul ettikleri için bu araştırmada da aynı yöntem esas alınmıştır. 


\section{Suriyeli Mültecilerin Türkçe Kursuna Başlamadan Önceki Söz Varlığı Durumları}

Bu araştırma durum çalışması ile desenlenmiş bir nitel araştırmadır. Nitel durum çalışmasının en temel özelliği bir ya da birkaç durumun derinlemesine araştırılmasıdır. Yani bir duruma ilişkin etkenler (ortam, bireyler, olaylar, süreçler vb.) bütüncül bir yaklaşımla araştırılır ve ilgili durumu nasıl etkiledikleri ve ilgili durumdan nasıl etkilendikleri üzerine odaklanılır. Veriler içerik analizi yöntemiyle yorumlanmıştır. İçerik analizinde temelde yapılan işlem, birbirine benzeyen verileri belirli kavramlar ve temalar etrafında bir araya getirmek ve yorumlamaktır (Yıldırım, Şimşek, 2013: 259). Bu çalışmada da Suriyeli genç kadın ve erkeklerin Türkiye'ye geldikten sonra herhangi bir Türkçe kursuna gitmeden sadece yaşayarak öğrendikleri Türkçe kelimelerin neler olduğu saptanmıştır.

\section{Verilerin Toplanması}

İstanbul Aydın Üniversitesi ve Uluslararası Mavi Hilal İnsani Yardım ve Kalkınma Vakfı iş birliği çerçevesinde Türkçe öğrenmek isteyen Suriyeli gençler için Türkçe kursları açımıştır. Bu kursa başvuran 275 öğrenciye seviye belirleme sınavı yapılmış ve ilgili öğrencilerin 90'ı sınavdan 20 puanın altında not alarak A1 seviyesinde Türkçe öğrenmeye başlamıştır. Bu kapsamda ilgili 90 öğrencinin söz varlığını tespit etmek üzere öğrencilere önce $A 1$ seviyesinde 2 basit konu verilmiş ve öğrencilerden bu konuyla ilgili yazı yazmaları istenmiştir. Fakat İlgili öğrenciler verilen konularda 2-3 satırı geçen yazı yazamadıkları için bu yöntemden vazgeçilmiş ve öğrencilerden sadece bildikleri Türkçe kelimeleri kâğıda yazmaları istenmiştir. Bu doğrultuda araştırmanın verileri öğrencilerin bildikleri Türkçe kelimelerden oluşmaktadır.

\section{Çalışma Grubu}

Araştırmanın çalışma grubunu İstanbul Aydın Üniversitesi'nde Türkçe öğrenmeye başlayacak olan 49 kadın 41 erkek A1 düzeyi Suriyeli genç kadın ve erkekler oluşturmuştur. Çalışmada amaçlı örnekleme yöntemlerinden kolay ulaşılabilir durum örneklemesi kullanılmıştır. Kolay ulaşılabilir durum örneklemesi, çoğu zaman araştırmacının diğer örnekleme yöntemlerini kullanma olanağının bulunmadığı durumlarda kullanılır (Yıldırım ve Şimşek, 2013: 141). Bu kapsamda araştırmanın çalışma grubuna ait bilgiler aşağıdaki gibidir:

Tablo 1. Suriyeli Genç Kadınların Türkiye'de Yaşadıkları Yıl ve Katılım Sayıları

\begin{tabular}{lcc}
\hline Cinsiyet & Türkiye'de Yaşama Yılı & Katılımcı Sayısı \\
\hline & 1 'den az & 6 \\
& 1 & 4 \\
Kadın & 2 yıl & 18 \\
& 3 yıl & 9 \\
& 4 yıl & 8 \\
\hline
\end{tabular}




\section{6 yıl}

Toplam
49

Yukarıdaki tablodan da anlaşılacağı üzere araştırmaya katılan kadınları 6’sı bir yıldan az, 4'ü bir yıl, 18'i iki yıl, 9'u üç yıl, 8'i dört yıl, 4'ü ise yıldan beri Türkiye'de yaşamaktadır. Türkiye'de yaşayan kadın katılımcı sayısı toplam 49 olarak tespit edilmiştir. Kadınlarda 6 yıl Türkiye' de yaşayan katılımcı sayısı hiç yokken en çok 2 yıl (18) yaşayan sayısı dikkat çekmektedir.

Tablo 2. Suriyeli Genç Erkeklerin Türkiye'de Yaşadıkları Yıl ve Katılım Sayıları

\begin{tabular}{ccc}
\hline Cinsiyet & Türkiye'de Yaşama Yılı & Katılımcı Sayısı \\
\hline & 1 'den az & 3 \\
& 1 yıl & 10 \\
& 2 yıl & 17 \\
& 3 yıl & 3 \\
& 4 yıl & 5 \\
& 5 yıl & 2 \\
\hline \multirow{2}{*}{ Toplam } & 6 yıl & 1 \\
\hline
\end{tabular}

Araştırmaya katılan genç erkeklerden 3 kişi bir yıldan az, 10 kişi bir yıl, 17 kişi iki yıl, 3 kişi üç yıl, 5 kişi dört yıl, 2 kişi beş yıl ve 1 kişi altı yıldan beri Türkiye'de yaşamaktadır. Türkiye'de yaşayan erkek katılımcı sayısı ise toplam 41 olarak tespit edilmiştir. Erkek katılımcılarda en çok katılım 1 yıl (10) ve 2 yıl (17) olarak ortaya çıkmıştır. Bu bilgilerden hareketle ilgili hem kadın hem erkek öğrencilerin ortalama 3-4 yıldır Türkiye'de yaşadıkları fakat buna rağmen Türkçe öğrenemedikleri dikkate alınması gereken bir konudur.

\section{Bulgular ve Yorum}

Bu bölümde araştırmanın problem cümlesi çerçevesinde alt problemlere ait bulgular ve yorumlar verilmiştir. Bu kapsamda araştırmanın bulguları aşağıdaki gibidir:

Suriyeli Mültecilerin;

"Türkçe söz varlığı durumları ne düzeydedir?” Sorusuna ilişkin bulgular aşağıdaki gibidir: 
Suriyeli Mültecilerin Türkçe Kursuna Başlamadan Önceki Söz Varlığı Durumları

Türkiye'de yaşayan Suriyeli gençlerin Türkçe kursuna gitmeden yaşayarak öğrendikleri kelimelerin analizi bu bölümde yer almaktadır.

Tablo 3. Suriyeli Genç Kadın ve Erkeklerin Bildikleri Toplam Kelime Sayısına Iliş̧in Veriler

\begin{tabular}{cccc}
\hline Cinsiyet & Katılımcı sayısı & Kelime & Ortalama Kelime Sayısı \\
\hline Kadın & 49 & 4931 & 100 \\
Erkek & 41 & 3974 & 96 \\
Toplam & 90 & 8905 & 196 \\
\hline
\end{tabular}

Tablo 3'e bakıldığında Türkçe kursuna gitmeden sosyal ortamda Türkçe öğrenen kadınların toplamda 4931 kelime bildiği, genç erkeklerin ise 3974 Türkçe kelime bilgisine sahip oldukları ortaya çıkmıştır. Cinsiyet ayırmaksızın bilinen toplam kelime sayısı ise 8905 olarak tespit edilmiştir. Bu kapsamda kadınlar ortalama 100 kelime bilmekte iken erkeklerde bu sayı 96'dır. Verilerden hareketle kadın ve erkek öğrencilerin bildikleri ortalama kelime sayısının hemen hemen aynı olduğu söylenebilir.

"Cinsiyetlerine göre bilinen kategorileşmiş söz varlığı durumları ne düzeydedir?” Sorusuna ilişkin bulgular aşağıdaki gibidir:

Aşağıdaki tabloda kız ve erkek öğrencilerin bildikleri kelimeler tekrarları göz ardı edilerek toplam olarak alınmış ve kategorilere ayrılmıştır.

Tablo 4. Cinsiyetlerine Göre Bilinen Kategorileşmiş Söz Varlığı Durumlarına iliş̧kin Veriler

\begin{tabular}{cccccccc}
\hline Cinsiyet & İsim & Fiil & Sifat & Zamir & Zarf & $\begin{array}{c}\text { Kalıp } \\
\text { ifadeler }\end{array}$ & Toplam \\
\hline Kadın & 3873 & 426 & 350 & 81 & 74 & 127 & 4931 \\
Erkek & 3235 & 263 & 193 & 75 & 90 & 118 & 3974 \\
Toplam & 7108 & 689 & 543 & 156 & 164 & 245 & 8905 \\
\hline
\end{tabular}

Yukarıdaki tabloya göre Suriyeli genç kadın ve erkeklerin tekrar eden kelimelerle beraber 8905 kelime bildikleri tespit edilmiştir. Kadın katılımcılar toplamda 4931 kelime bilirken erkek katılımcıların kelime sayısı 3974 olarak analiz edilmiştir. Gençlerin Türkçe 7108 isim, 689 fiil, 543 sıfat, 156 zamir ve 245 kalıp ifade bilgisine sahip oldukları ortaya çıkmıştır. Bu kapsamda kadın katılımcıların bildikleri kelimelerin $3873^{\prime}$ ü isim 426'sı fiil, 350'si sıfat, 81'i zamir, 74'ü zarf ve 127'si kalıp ifade iken erkeklerin 
bildiği kelimelerin 3235’i isim, 263'ü fiil, 193'ü sıfat, 75’i zamir, 90’ı zarf ve 118'i kalıp sözdür. Bu bulgulardan hareketle ilgili öğrencilerin özellikle A1 seviyesinde öğretilen kelime bilgisine sahip oldukları söylenebilir.

"Türkiye'de yaşadıkları yıllara göre söz varlığı durumları ne düzeydedir?" Sorusuna ilişkin bulgular aşağıdaki gibidir:

Suriyeli gençlerin Türkiye'de yaşadıkları yıllar temel alındığında bilinen kelime sayıları aşağıdaki tabloyu oluşturmuştur.

Tablo 5. Suriyeli Genç Kadın ve Erkeklerin Türkiye’de Yaşadıkları Yıllara Göre Kelime Dağııımı

\begin{tabular}{|c|c|c|c|c|}
\hline Cinsiyet & YII & Katılımcı Sayısı & Kelime Sayısı & Toplam \\
\hline \multirow{7}{*}{ Kadın } & 1'den az & 6 & 397 & \multirow{7}{*}{4931} \\
\hline & 1 yıl & 4 & 611 & \\
\hline & 2 yıl & 18 & 1885 & \\
\hline & $3 \mathrm{yll}$ & 9 & 1177 & \\
\hline & $4 \mathrm{yll}$ & 8 & 475 & \\
\hline & $5 \mathrm{yll}$ & 4 & 386 & \\
\hline & $6 \mathrm{yll}$ & - & - & \\
\hline \multirow{7}{*}{ Erkek } & 1'den az & 3 & 192 & \multirow{7}{*}{3974} \\
\hline & $1 \mathrm{yll}$ & 10 & 887 & \\
\hline & $2 \mathrm{yll}$ & 17 & 1616 & \\
\hline & $3 \mathrm{yll}$ & 3 & 173 & \\
\hline & $4 \mathrm{yll}$ & 5 & 824 & \\
\hline & 5 yıl & 2 & 148 & \\
\hline & $6 \mathrm{yll}$ & 1 & 134 & \\
\hline Toplam & & 90 & 8905 & 8905 \\
\hline
\end{tabular}

Tablo analiz edildiğinde Türkiye'de 1 yıldan az yaşayan gençlerin 589 kelime ( K/6 - E/3), 1 yıl yaşayan gençlerin 1498 kelime (K/4-E/10), 2 yıl yaşayan gençlerin 3501 kelime (K/18-E/17), 3 yıl yaşayan gençlerin 1350 kelime (K/9-E/3), 4 yıl yaşayan gençlerin 1299 kelime (K/8-E/5), 5 yıl yaşayan gençlerin 534 kelime (K/4-E/2) ve 6 yıl yaşayan gençlerin ise 134 (E/1) kelime bildikleri ortaya çıkmıştır.

"Bildikleri tekrarsız kelime sayısı ne düzeydedir?" Sorusuna ilişkin bulgular aşağıdaki gibidir:

Suriyeli genç kadın ve erkeklerin tekrarsız kelime bilgileri tablo 6'da gösterilmiştir.

Tablo 6. Suriyeli Genç Kadın ve Erkeklerin Tekrarsız Kelime Sayıları

\begin{tabular}{|c|c|c|c|c|c|c|c|}
\hline Cinsiyet & İsim & Fiil & Sifat & Zamir & Zarf & $\begin{array}{l}\text { Kalıp } \\
\text { Ifadeler }\end{array}$ & Toplam \\
\hline
\end{tabular}


Suriyeli Mültecilerin Türkçe Kursuna Başlamadan Önceki Söz Varlığı Durumları

\begin{tabular}{ccccccccc}
\hline Kadın & 623 & 127 & 85 & 16 & 24 & 33 & 908 & 817 \\
Erkek & 579 & 100 & 56 & 14 & 31 & 37 & 70 & 1825 \\
Toplam & 1202 & 327 & 141 & 30 & 55 & 70 \\
\hline
\end{tabular}

Tablo incelendiğinde tekrarsız kelime sayılarının toplam 1825 olduğu görülmektedir. Burada esas amaç Suriyeli gençlerin kaç çeşit kelime bildiklerini ortaya çıkarmaktır. Genç kadınlar toplamda 908 farklı kelime bilgisine sahipken genç erkekler toplamda 817 farklı kelime bilgisine sahiptir. Kadın katılımcıların daha çok kelime bildiği dikkat çekmektedir. Fakat kadın katılımcı sayısı erkek katılımcı sayısına oranla daha yüksektir.

"En çok tekrar ettiği kelimeler nelerdir?" Sorusuna ilişkin bulgular aşağıdaki gibidir:

Tablo 7. Suriyeli Genç Kadın ve Erkekler Tarafından En Çok Tekrar Edilen Kelimeler

\begin{tabular}{ccccc}
\hline & Kadın & Tekrar Sayısı & Erkek & Tekrar Sayısı \\
\hline & Saat & 42 & Kitap & 35 \\
& Kalem & 40 & Defter & 34 \\
& Kitap & 38 & Kalem & 32 \\
\hline En çok & Masa & 37 & Saat & 31 \\
Tekrar & Tahta & 37 & Tahta & 31 \\
& Araba & 35 & Araba & 30 \\
& Çanta & 35 & Çanta & 30 \\
& Öğretmen & 35 & Masa & 30 \\
\hline & Okul & 33 & Öğrenci & 30 \\
\hline
\end{tabular}

Suriyeli genç kadınların en çok tekrar ettikleri kelimelerin sırasıyla saat (42), kalem (40), kitap (38), masa (37), tahta (37), araba (35), çanta (35), öğretmen (35), okul (33) ve öğrenci (32) olduğu tespit edilmiştir. Erkeklerin en çok tekrar ettiği kelimelerin ise sırasıyla kitap (35), defter (34), kalem (32), saat (31), tahta (31), araba (30), çanta (30), masa (30), öğrenci (30) ve okul (29) olduğu ortaya çıkmıştır. Hem erkeklerin hem de kadınların en çok kullandığı ortak kelimeler arasında masa, tahta, kalem, araba, çanta, 
kitap, saat, okul ve öğrenci kelimelerinin varlığı ilgili katılımcıların genel olarak okul araç ve gereçlerini bilmeleri okul çağında olmaları nedeni ile dikkat çekmektedir.

"Söz varlığı durumlarının temalara göre dağılımı nasıldır?" Sorusuna ilişkin kategori şeklinde sınıflandırılmış kelimeler ve bu kelimelerin sayılarına yer veren bulgular aşağıdaki gibidir:

Eğitim kategorisine ait kelimeler tablo aracılığı ile gösterilmiştir.

Tablo 8. Eğitim Kategorisine ait Kelimeler ve Sayıları

\begin{tabular}{cccc}
\hline Kelimeler & Kadın & Erkek & Toplam \\
\hline Kitap & 38 & 35 & 73 \\
\hline Kalem & 40 & 32 & 72 \\
\hline Tahta & 37 & 31 & 68 \\
Masa & 37 & 30 & 65 \\
Çanta & 35 & 30 & 62 \\
\hline Ögrenci & 32 & 30 & 62 \\
Okul & 33 & 29 & 59 \\
\hline Öğretmen & 35 & 24 & 58 \\
Silgi & 30 & 28 & 56 \\
\hline Sandalye & 29 & 27 & 40 \\
Bilgisayar & 18 & 22 & 35 \\
Üniversite & 13 & 22 & 34 \\
\hline Defter & - & 34 & 21 \\
Ders & - & 21 & 17 \\
Cetvel & 17 & - & 16 \\
Hoca & 6 & 10 & 14 \\
Ödev & 9 & 5 & 10 \\
Sınav & 7 & 6 & 8 \\
\hline Sözlük & 7 & 3 & 6 \\
Teneffüs & 6 & 2 & 4 \\
Sıra & 6 & - & 3 \\
Pergel & 3 & 1 & 2 \\
Lise & 1 & 2 & 2 \\
Kütüphane & - & 2 & 1 \\
\hline Kırtasiye & - & 2 & \\
Fakülte & - & 1 & \\
\hline & & & 13 \\
\hline
\end{tabular}

Eğitim kategorisine ait kelimelerin sınıflandırılmasında katılımcılar arasında en çok tekrar eden ilk beş kelimenin kitap (73), kalem (72), tahta (68), masa (67) ve çanta (65) olduğu tespit edilirken; en az tekrar eden son beş kelimenin ise pergel (4), lise (3) kütüphane (2), kırtasiye (2) ve fakülte (1) olduğu ortaya çıkmıştır. Toplamda 90 katılımcıdan 73'ünün kitap kelimesini tekrar etmesinin büyük bir oran olduğu dikkat çekmektedir. Bu durum ise ilgili çalışma grubun öğrencilerden oluşmasına bağlanabilir. 
Suriyeli Mültecilerin Türkçe Kursuna Başlamadan Önceki Söz Varlığı Durumları

Tablo 9. Aile Kategorisine Ait Kelimeler ve Sayıları

\begin{tabular}{cccc}
\hline Kelime & Kadın & Erkek & Toplam \\
\hline Anne & 33 & 23 & 56 \\
Baba & 32 & 21 & 53 \\
Kardeş & 17 & 14 & 31 \\
Çocuk & 9 & 9 & 18 \\
Bebek & 18 & - & 18 \\
Ağabey & 6 & 6 & 12 \\
Amca & 8 & 4 & 12 \\
\hline Teyze & 7 & 5 & 12 \\
Abla & 10 & - & 10 \\
Dede & 5 & 5 & 10 \\
Hala & 6 & 4 & 10 \\
Dayı & 4 & 5 & 9 \\
Eş & 5 & 1 & 6 \\
Babaanne & 4 & - & 4 \\
Anneanne & 3 & - & 3 \\
Oğul & 1 & 2 & 3 \\
Akraba & 2 & - & 2 \\
Büyükanne & - & 1 & 1 \\
Koca & 1 & - & 1 \\
Nine & 1 & - & 1 \\
\hline
\end{tabular}

Aile kategorisinde katılımcıların en çok bildiği kelimeler arasında anne (56), baba (53), kardeş (31), çocuk (18), ağabey (12), amca (12) ve teyzenin (12) olduğu görülmüştür. Suriyeli genç kadınlar büyükanne (1) kelimesini hiç kullanmazken erkekler de bebek (18), abla (10), babaanne (4), anneanne (3), koca (1) ve nine (1) kelimelerini hiç kullanmamışlardır.

Tablo 10. Meslek Kategorisine Ait Bilinen Kelimeler ve Sayıları

\begin{tabular}{cccc}
\hline Kelimeler & Kadın & Erkek & Toplam \\
\hline Öğretmen & 35 & 24 & 59 \\
Doktor & 25 & 15 & 40 \\
Polis & 11 & 11 & 22 \\
Hoca & 6 & 10 & 16 \\
Mühendis & 16 & - & 16 \\
Hemşire & 10 & 4 & 14 \\
Kasap & 7 & 2 & 9 \\
Bakkal & - & 6 & 6 \\
Sekreter & 4 & 2 & 6 \\
Avukat & 5 & - & 5 \\
Ev hanımı & 2 & 3 & 5 \\
Müdür & 2 & 3 & 5 \\
Şarkıcı & 5 & - & 5 \\
Futbolcu & - & 4 & 4 \\
\hline
\end{tabular}




\begin{tabular}{cccc}
\hline Güvenlik & 1 & 3 & 4 \\
Jandarma & 4 & - & 4 \\
Kuaför & 2 & 1 & 3 \\
Asker & 1 & 1 & 2 \\
Emekli & 1 & 1 & 2 \\
\hline
\end{tabular}

Mesleklere ait tablo incelendiğinde katılımcıların en çok tekrar ettiği kelimelerin arasında öğretmen (59), doktor (40), polis (22), hoca (16), mühendis (16) ve hemşire (14) olduğu tespit edilmiştir. Emekli (2) ve asker (2) kelimeleri bir kadın ve bir erkek katılımcı tarafından bilinerek listenin son sırasında yer almıştır. Erkek katılımcılar mühendis (16), avukat (5) ve şarkıcı (5) kelimelerini hiç kullanmazken kadın katılımcılar de bakkal (6) ve futbolcu (4) kelimelerini hiç kullanmamıştır.

Tablo 11. Renk Kategorisine Ait Bilinen Kelimeler ve Sayıları

\begin{tabular}{cccc}
\hline Kelimeler & Kadın & Erkek & Toplam \\
\hline Mavi & 21 & 15 & 36 \\
Kımızı & 20 & 14 & 34 \\
Siyah & 12 & 13 & 26 \\
Beyaz & 18 & 7 & 25 \\
Yeşil & 14 & 7 & 21 \\
Pembe & 10 & 2 & 12 \\
Mor & 5 & 5 & 10 \\
Sarı & 6 & - & 6 \\
Gri & 2 & - & 2 \\
Turuncu & 1 & 1 & 2 \\
Bordo & - & 1 & 1 \\
\hline Kahverengi & - & 1 & 1 \\
\hline
\end{tabular}

Suriyeli gençlerin en çok tekrar ettikleri kelimeler arasında mavi (36), kırmızı (34), siyah (26), beyaz (25) ve yeşil (21) olduğu ortaya çıkmıştır. En az kullanılan renk bir erkek ve bir kadın katıımcıyla turuncu (2) olmuştur. Erkek katılımcıların kadın katıımcılar dışında kahverengi (1) ve bordo (1) renklerini bildikleri, kadın katılımcıların ise sarı (6) ve gri (2) renklerini bildikleri tespit edilmiştir.

Tablo 12. Meyve Kategorisine Ait Bilinen Kelimeler ve Sayıları

\begin{tabular}{lllll}
\hline Kelimeler & Kadın & Erkek & Toplam \\
\hline
\end{tabular}


Suriyeli Mültecilerin Türkçe Kursuna Başlamadan Önceki Söz Varlığı Durumları

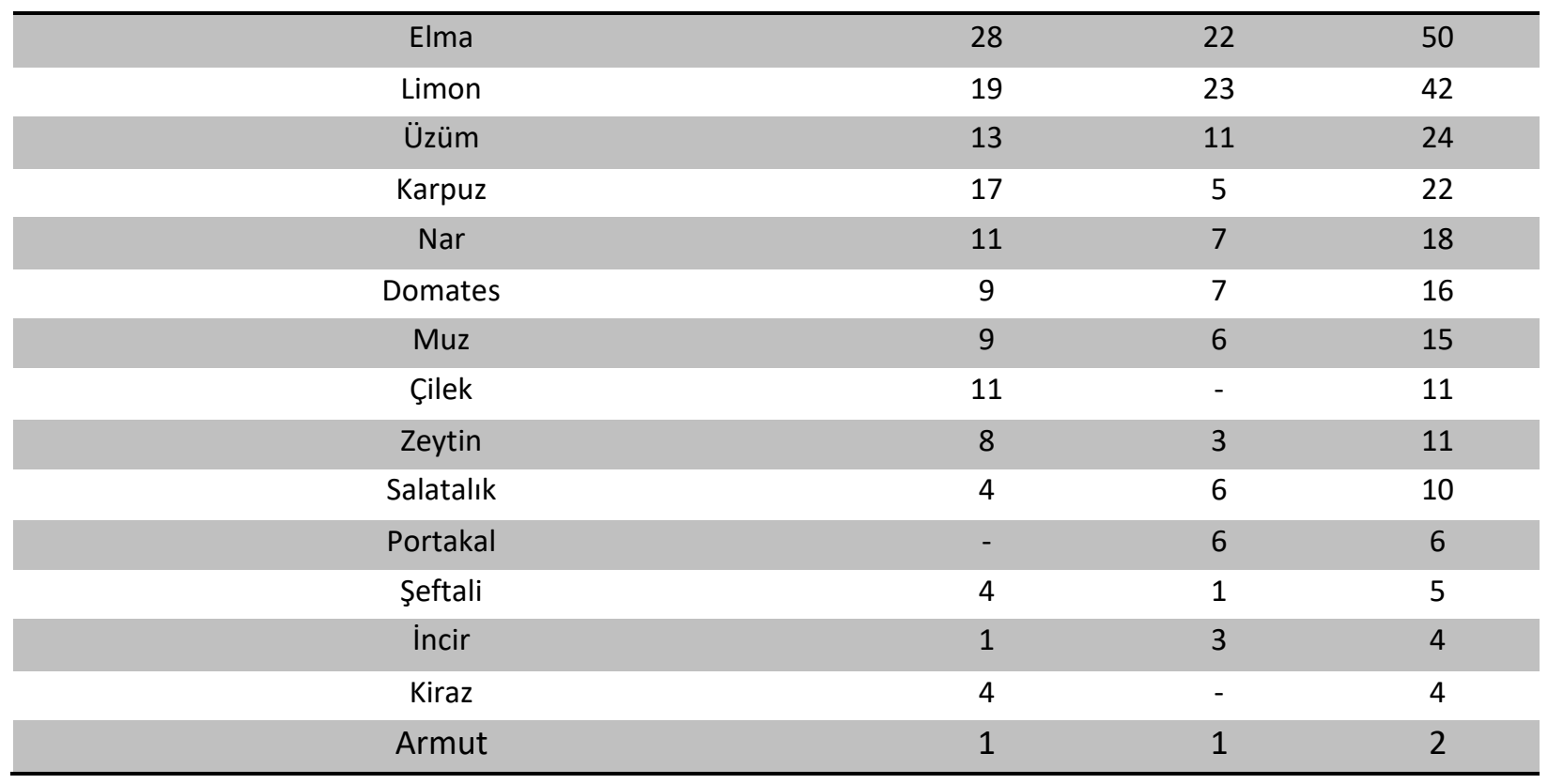

Meyveler kategorisinde en çok tekrar edilen kelimeler elma (50), limon (42), üzüm (24), karpuz (22) ve nar (18) olarak saptanmıştır. Kiraz ve incir dört kez tekrar edilirken armut (2) bir kadın bir erkek katılımcı tarafından birer kez tekrar edilmiştir. Erkek katılımcıların çilek (11) ve kirazı (4) bilmedikleri ortaya çıkarken kadın katılımcıların da portakalı (6) bilmedikleri ortaya çıkmıştır.

Tablo 13. Insan Vücudu Kategorisine Ait Kelimeler ve Sayılar

\begin{tabular}{cccc}
\hline Kelimeler & Kadın & Erkek & Toplam \\
\hline Göz & 37 & 28 & 65 \\
Saç & 25 & 21 & 46 \\
Diş & 17 & 11 & 27 \\
El & 13 & 15 & 25 \\
Burun & 12 & 10 & 22 \\
Ayak & 11 & 8 & 19 \\
Parmak & 10 & 8 & 18 \\
Dil & 7 & 9 & 16 \\
Kulak & 10 & 5 & 15 \\
Kaş & 11 & 3 & 14 \\
Ağız & 4 & 6 & 10 \\
Tırnak & 8 & 2 & 10 \\
Baş & 4 & 4 & 8 \\
Yanak & 5 & - & 5 \\
Çene & 5 & - & 4 \\
Bilek & 4 & 2 & 3 \\
Boğaz & 1 & - & 3 \\
Dirsek & 3 & 1 & 3 \\
\hline
\end{tabular}




\begin{tabular}{ccccc}
\hline Göğüs & 1 & 2 & 3 \\
Kol & 3 & - & 3 \\
\hline
\end{tabular}

Tablo 13 incelendiğinde Suriyeli genç kadın ve erkeklerin insan vücuduyla ilgili en çok bildikleri kelimeler arasında göz (65), saç (46), diş (27), el (25) ve burun (22) olduğu saptanmıştır. Bilek, boğaz, dirsek, göğüs ve kol kelimeleri sadece 3 kez tekrar ederek listenin en sonunda yer almıştır. Kadın katılımcılar erkek katılımcılardan farklı olarak yanak (5), çene (4), boğaz (3) ve kol (3) kelimelerini bilirken erkek katılımcıların kadınlar dışında bir kelime bilmedikleri tespit edilmiştir.

Tablo 24. Hayvan Kategorisine Ait Kelimeler ve Sayıları

\begin{tabular}{|c|c|c|c|}
\hline Kelimeler & Kadın & Erkek & Toplam \\
\hline Köpek & 32 & 17 & 49 \\
\hline İnek & 19 & 21 & 40 \\
\hline Kedi & 26 & 9 & 35 \\
\hline Fare & 16 & 13 & 29 \\
\hline Fil & 16 & 11 & 27 \\
\hline Balık & 17 & 9 & 26 \\
\hline Civciv & 13 & 9 & 22 \\
\hline Tavuk & 11 & 10 & 21 \\
\hline Ördek & 8 & 9 & 17 \\
\hline Aslan & 4 & 8 & 12 \\
\hline Eşek & 3 & 9 & 12 \\
\hline Maymun & 6 & 4 & 10 \\
\hline At & 5 & 4 & 9 \\
\hline Zürafa & 9 & - & 9 \\
\hline Ayı & 2 & 4 & 6 \\
\hline Tavşan & 5 & - & 5 \\
\hline Yılan & 3 & 2 & 5 \\
\hline Böcek & - & 1 & 1 \\
\hline Deve & 1 & - & 1 \\
\hline Horoz & - & 1 & 1 \\
\hline Kurt & - & 1 & 1 \\
\hline
\end{tabular}

Hayvan kategorisine ait Suriyeli gençlerin en çok kullandığı kelimeler arasında köpek (49), inek (40), kedi (35), fare (29) ve filin (27) olduğu tespit edilmiştir. Üç kadın ve iki erkek tarafından yazılan yılan en az kullanılan kelime olarak görülmüştür. Erkeklerin kullanıp kadın katılımcıların kullanmadığı kelimeler arasında horoz (1), böcek (1) ve kurt (1) yerini alırken erkek katılımcıların ise zürafa (9), tavşan (5) ve deve (1) kelimelerini kullanmadıkları ortaya çıkmıştır. 
Suriyeli Mültecilerin Türkçe Kursuna Başlamadan Önceki Söz Varlığı Durumları

Tablo 35. Sayılar Kategorisine Ait Kelimeler ve Sayıları

\begin{tabular}{ccccc}
\hline Kelimeler & Kadın & Erkek & Toplam \\
\hline İki & 13 & 10 & 23 \\
\hline Yüz & 8 & 15 & 23 \\
Bir & 12 & 10 & 22 \\
\hline Dört & 11 & 9 & 20 \\
Ü̧̧ & 9 & 9 & 18 \\
Beş & 9 & 8 & 17 \\
On & 8 & 9 & 17 \\
Altı & 6 & 6 & 12 \\
Yedi & 5 & 7 & 12 \\
Sekiz & 6 & 5 & 11 \\
Dokuz & 5 & 5 & 10 \\
Otuz & 4 & 4 & 8 \\
Elli & 4 & 3 & 7 \\
Doksan & 4 & 3 & 7 \\
Kırk & 4 & 3 & 7 \\
Seksen & 4 & 3 & 7 \\
Yirmi & 4 & 3 & 7 \\
Altmış & 4 & 2 & 6 \\
Yetmiş & 4 & 2 & 6 \\
\hline
\end{tabular}

Tablo 15 incelendiğinde katılımcıların en sık tekrar ettikleri sayıların iki (23), yüz (23), bir (22), dört (20) ve üç (18) olduğu ortaya çıkmıştır. En az tekrar eden sayılar ise altmış (6) ve yetmiş (6) olarak görülmektedir. Tablodan hareketle Suriyeli genç kadın ve erkeklerin Türkçede ana hatlarıyla sayıları bildiği saptanmıştır.

Tablo 46. Toplu Taşıma Kategorisine Ait Kelimeler ve Sayıları

\begin{tabular}{cccc}
\hline Kelimeler & Kadın & Erkek & Toplam \\
\hline Otobüs & 25 & 19 & 34 \\
Uçak & 20 & 11 & 31 \\
Metrobüs & 6 & 7 & 13 \\
Gemi & 6 & 5 & 11 \\
Metro & 5 & 5 & 10 \\
Vapur & 1 & 5 & 6 \\
Durak & 1 & 4 & 5 \\
Tren & 4 & 1 & 5 \\
Tramvay & - & 4 & 4 \\
İstasyon & 2 & 1 & 3 \\
Taksi & 1 & 1 & 2 \\
\hline
\end{tabular}


Toplu taşıma kategorisine ait kelimeler arasında en sık tekrar edenlerin otobüs (34), uçak (31), metrobüs (13), gemi (11) ve metro (10) olduğu ortaya çıkmıştır. En az tekrar eden kelime ise bir erkek katılımcı ve bir kadın katılımcıyla taksi (2) olmuştur. Erkek katılımcılar tramvay (4) kelimesini de öğrenmişlerdir.

Tablo 57. Din Kategorisine Ait Kelimeler ve Sayıları

\begin{tabular}{cccc}
\hline Kelimeler & Kadın & Erkek & Toplam \\
\hline Cami & 16 & 14 & 30 \\
Bayram & 8 & 6 & 14 \\
Namaz & 3 & 4 & 7 \\
Abdest & 2 & - & 2 \\
Mescid & 1 & 1 & 2 \\
Oruç & 2 & - & 2 \\
Peygamber & - & 1 & 1 \\
Ramazan & 1 & - & 1 \\
\hline
\end{tabular}

Suriyeli gençlerin din ile ilgili kullandıkları kelimeler arasında en sık tekrar edilen cami (30) ve bayram (14) olarak tespit edilmiştir. Mescid (2) kelimesinin bir kadın ve bir erkek katılımcının kullanımıyla en az tekrar edilen kelime olduğu ortaya çıkmıştır. Erkek katılımcılar abdest (2) ve oruç (2) kelimelerini kullanmazken kadın katılımcılar da peygamber (1) kelimesini kullanmadıkları sonucuna varılmıştır.

Tablo 68. Günler ve Mevsimler Kategorisine Ait Kelimeler ve Sayıları

\begin{tabular}{cccc}
\hline Kelimeler & Kadın & Erkek & Toplam \\
\hline Pazar & 18 & 10 & 28 \\
Cuma & 15 & 8 & 23 \\
Pazartesi & 13 & 8 & 21 \\
Cumartesi & 9 & 7 & 16 \\
Salı & 10 & 5 & 15 \\
Çarşamba & 9 & 6 & 14 \\
Perşembe & 9 & 5 & 14 \\
Yaz & 7 & 7 & 14 \\
Konş & 8 & 5 & 13 \\
IIlkbahar & 6 & 4 & 10 \\
\hline
\end{tabular}

Tablo 18 incelendiğinde öğrenciler tarafından en çok tekrar eden kelimelerin pazar (28), cuma (23), pazartesi (21), cumartesi (16) ve salı (15) olduğu analiz edilmiştir. Illkbahar mevsimine ait olan 
kelime ise dört kadın katılımcı ve dört erkek katılımcı tarafından tekrar edilerek listenin en son sırasında yer almıştır.

Tablo 79. Fiil Kategorisine Ait Kelimeler ve Sayıları

\begin{tabular}{|c|c|c|c|}
\hline Kelimeler & Kadın & Erkek & Toplam \\
\hline Gel- & 22 & 12 & 34 \\
\hline Yaz- & 15 & 10 & 25 \\
\hline Ye- & 12 & 12 & 24 \\
\hline Git- & 22 & - & 22 \\
\hline Al- & 12 & 9 & 21 \\
\hline Sev- & 13 & 8 & 21 \\
\hline Oku- & 13 & 4 & 17 \\
\hline Ver- & 11 & 6 & 17 \\
\hline Yap- & 9 & 8 & 17 \\
\hline Otur- & 10 & 6 & 16 \\
\hline Koş- & 9 & 6 & 15 \\
\hline Aç- & 7 & 7 & 14 \\
\hline Bil- & 7 & 7 & 14 \\
\hline Konuş- & 9 & 5 & 14 \\
\hline Çalış- & 7 & 5 & 12 \\
\hline İste- & 7 & 5 & 12 \\
\hline Bak- & 7 & 4 & 11 \\
\hline Kal- & 6 & 5 & 11 \\
\hline Dinle- & 7 & 3 & 10 \\
\hline Gör- & 7 & 3 & 10 \\
\hline |̧̧̇- & 6 & 4 & 10 \\
\hline Uyu- & 5 & 3 & 8 \\
\hline Bekle- & 6 & - & 6 \\
\hline Özle- & 6 & - & 6 \\
\hline Öl- & - & 5 & 5 \\
\hline Yat- & 5 & - & 5 \\
\hline Yüz- & 5 & - & 5 \\
\hline Kapat- & - & 4 & 4 \\
\hline Geç- & - & 3 & 3 \\
\hline Sil- & - & 3 & 3 \\
\hline Sus- & 3 & - & 3 \\
\hline
\end{tabular}

Fiillere ait kategori incelendiğinde katılımcılar arasında en fazla tekrar edilen kelimelerin gelmek (34), yazmak (25), yemek (24), gitmek (22), almak (21) ve sevmek (21) olduğu ortaya çıkmıştır. Beş kadın katılımııın ve üç erkek katılımcının tekrarlarıyla da uyumak (8) fiilinin en az tekrar eden ortak fiil olduğu tespit edilmiştir. Ayrıca erkek katılımcılar gitmek (22), beklemek (6), özlemek (5), yüzmek (5), yatmak (5) ve susmak (5) fiillerini hiç kullanmazken kadın katılımcılar da ölmek (5), kapatmak (4), geçmek (3) ve silmek (3) fiillerini hiç kullanmamışlardır. 
Tablo 20. SIfat Kategorisine Ait Kelimeler ve Sayıları

\begin{tabular}{|c|c|c|c|}
\hline Kelimeler & Kadın & Erkek & Toplam \\
\hline Güzel & 17 & 15 & 32 \\
\hline Çok & 17 & 11 & 28 \\
\hline İyi & 11 & 9 & 20 \\
\hline Mutlu & 10 & 7 & 17 \\
\hline Büyük & 9 & 7 & 16 \\
\hline $\mathrm{Az}$ & 9 & 6 & 15 \\
\hline Şişman & 8 & 7 & 15 \\
\hline Uzun & 8 & 7 & 15 \\
\hline Kötü & 10 & 4 & 14 \\
\hline Kısa & 7 & 6 & 13 \\
\hline Yakın & 9 & 4 & 13 \\
\hline Küçük & 6 & 6 & 12 \\
\hline Tatlı & 8 & 4 & 12 \\
\hline Uzak & 8 & 4 & 12 \\
\hline Yeni & 6 & 5 & 11 \\
\hline Temiz & 7 & 3 & 10 \\
\hline Zayıf & 5 & 4 & 9 \\
\hline Zor & 6 & 2 & 8 \\
\hline Çalışkan & 5 & 2 & 7 \\
\hline Kolay & 5 & 2 & 7 \\
\hline Kalabalık & 6 & - & 6 \\
\hline İnce & 5 & - & 5 \\
\hline Mutsuz & 5 & - & 5 \\
\hline Güçlü & - & 3 & 3 \\
\hline Korkak & - & 3 & 3 \\
\hline Şanslı & - & 1 & 1 \\
\hline
\end{tabular}

Sıfat kategorisine ait tabloya bakıldığında katılımcıların en sık tekrar ettikleri kelimeler arasında güzel (32), çok (28), iyi (20), mutlu (17) ve büyük (16) kelimelerinin olduğu tespit edilmiştir. Beş kadın katılımcı ve iki erkek katııımcının tekrar sıklığıyla en az kullanılan kelimeler kolay (7) ve çalışkan (7)'dır. Erkek katılımcılar kadın katılımcılardan farklı olarak korkak (3), güçlü (3) ve şanslı (1) sıfatlarını kullanırken kadın katılımcılar ise kalabalık (6), ince (5) ve mutsuz (5) sıfatlarını kullanmışlardır.

Tablo 21. Zamir Kategorisine Ait Kelimeler ve Sayıları 
Suriyeli Mültecilerin Türkçe Kursuna Başlamadan Önceki Söz Varlığı Durumları

\begin{tabular}{ccccc}
\hline Ben & 12 & 14 & 26 \\
Sen & 12 & 11 & 23 \\
O & 9 & 9 & 18 \\
Biz & 7 & 10 & 17 \\
Onlar & 9 & 7 & 16 \\
Kim & 8 & 6 & 14 \\
Siz & 9 & 5 & 14 \\
Ne & 8 & 4 & 12 \\
Burası & 1 & 2 & 3 \\
Şurası & 1 & 2 & 3 \\
\hline
\end{tabular}

Suriyeli gençlerin ben (26), sen (23), o (18), biz (17) ve onlar (16) zamirlerini fazla tekrar ettikleri tespit edilmiştir. En az tekrar edilen zamirler ise burası (3) ve şurası (3) kelimeleri olmuştur.

Tablo 22. Zarf Kategorisine Ait Kelimeler ve Sayıları

\begin{tabular}{ccccc}
\hline Kelimeler & Kadın & Erkek & \multicolumn{1}{c}{ Toplam } \\
\hline Akşam & 13 & 9 & 22 \\
\hline Nerede & 9 & 3 & 12 \\
\hline Sabah & 6 & 6 & 12 \\
\hline Dün & 5 & 6 & 11 \\
\hline Sonra & 4 & 6 & 10 \\
\hline Yarın & 4 & 7 & 10 \\
\hline Şimdi & 2 & 3 & 9 \\
\hline Bugün & 4 & 3 & 7 \\
\hline Burada & 3 & 1 & 6 \\
\hline Neden & 3 & 1 & 4 \\
\hline Nereye & 3 & 2 & 4 \\
\hline Hiç & 1 & 2 & 3 \\
\hline İçeri & 1 & - & 3 \\
\hline Ne kadar & 3 & 2 & 3 \\
\hline Oradada & 3 & 1 & 3 \\
\hline Nasıl & 1 & 2 & 3 \\
\hline Öğlen & 2 & 1 & 2 \\
\hline
\end{tabular}

Tablo 22 incelendiğinde katılımcıların en çok bildikleri kelimeler arasında akşam (22), nerede (12), sabah (12), dün (10) ve sonra (10) zarflarının olduğu tespit edilmiştir. En az tekrar edilen kelimeler arasında ise hiç (3), içeri (3), ne kadar (3), şurada (3), orada (3), nasıl (2) ve öğlen (2) kelimeleri yer almıştır. Erkek katılımcılar ne kadar (3) kelimesini hiç kullanmazken kadın katılımcıların da nasıl (2) kelimesini hiç kullanmadıkları ortaya çıkmıştır

"Kalıp sözlere yönelik söz varlığı ne düzeydedir?" Sorusuna ilişkin bulgular aşağıdaki gibidir: 
Tablo 238. Kalıp Ifadeler Kategorisine Ait Kelimeler ve Sayıları

\begin{tabular}{cccc}
\hline Kelimeler & Kadın & Erkek & Toplam \\
\hline Merhaba & 12 & 15 & 27 \\
Nasılsın & 13 & 6 & 19 \\
Evet & 9 & 9 & 18 \\
Güle güle & 6 & 9 & 14 \\
Hayır & 7 & 7 & 14 \\
Günaydın & 9 & 3 & 12 \\
İyi akşamlar & 6 & 4 & 10 \\
Iyi günler & 5 & 5 & 10 \\
Hoş geldin & 5 & 4 & 9 \\
Nerelisin & 8 & 1 & 9 \\
Tamam & 6 & 3 & 9 \\
İyiyim & 6 & 2 & 7 \\
Hoşça kal & 6 & 7 \\
Memnun oldum & 2 & 5 & 6 \\
Hoş bulduk & 4 & 3 & 6 \\
Özür dilerim & 4 & 2 & 5 \\
Iyi geceler & 3 & 3 & 5 \\
Sağ ol & 1 & 5 \\
Selam & 4 & 3 \\
Teşekkür ederim & - & 5 & 3 \\
Bol şanslar & 2 & 3 & 2 \\
\hline Tebrikler & 1 & 2 & \\
\hline
\end{tabular}

Suriyeli gençlerin Türkçedeki kalıp ifadeleri kullanma sıklıklarına bakıldığında en çok merhaba (27), nasılsın (19), evet (18), güle güle (14) ve hayır (14) ifadelerini kullandıkları ortaya çıkmıştır. Katılımcıların ortak kullanım gösterdikleri kalıp ifadelerde en az kullanılanlar arasında teşekkür ederim (3) ve bol şanslar (3) tespit edilmiştir. Kadın katılımcılar erkek katılımcılardan farklı olarak tebrikler (2) ifadesini kullanırken erkek katılımcılar kadın katılımcılardan farklı olarak sağ ol (5) ifadesini kullanmışlardır. Yukarıdaki bulgulardan hareketle hem Diller İçin Avrupa Ortak Önerileri Çerçevesi hem de bu alanda kullanılan ders kitapları göz önünde bulundurulduğunda öğrencilerin A1 seviyesinde öğretilen kelimelerin çoğunu bildikleri söylenebilir.

\section{Sonuç ve Tartışma}

İlgili alanda yapılan çalışmalara bakıldığında, Şimşek (2015) çalışmasında, yabancılara Türkçe öğreten ders kitaplarından Lale ve İstanbul'un A1 seviyesini temel alarak okuma metinlerinde kalıp sözleri değerlendirmiştir. Şimşek'e göre bir dilin öğretilmesinde önemli bir yer kaplayan kültür aktarımını iletmek A1 seviyesinde sık sık kalıp sözlere yer vermekle sağlanmaktadır. Çalışmada karşılıklı konuşmalardan oluşan metinlerin ilişkisel söz varlığı açısından zengin olduğu tespit edilmiştir. Açık (2013) 


\section{Suriyeli Mültecilerin Türkçe Kursuna Başlamadan Önceki Söz Varlığı Durumları}

araştırmasında, Yazılı Türkçenin Kelime Sıklığı Sözlüğünden faydalanılarak temel seviyede öğrencilere öğretilebilecek kelimelere ve bu kelimelerin nasıl öğretilmesi gerektiği konusuna değinmiştir. Büyükikiz ve Hasırcı (2013) araştırmasında, sözcük öğretiminde en önemli hususlardan birinin temel söz varlı̆̆ının belirlenmesi gerektiğini savunmaktadır. Büyükikiz ve Hasırcı'ya göre söz varlığı belirlenirken kelimenin kullanım sıklığı, kullanılabilirliği, konuşma dili ile yazı dili arasındaki farklılık, hedef kitlenin ihtiyaçları ve dildeki değişimler de göz önünde bulundurulmalıdır.

Aşık (2007) da yüksek lisans tezinde Türkçe öğrenen yabancı uyruklu öğrencilerin hangi kelimeleri öğrenerek kelime öğretiminde başarı yakalayacaklarını tespit etmiştir. Araştırma sonucunda 304.479 kelime üzerinde kelime sıklığı çalışması yapılmış ve Türkçenin kelime sıklığını belirleyerek yabancı dil olarak Türkçenin öğretilmesinde öncelik verilmesi gereken kelimeler ortaya çıkarılmıştır. Son olarak Barın (2003) ise temel söz varlığını belirlemek için yalnızca yazılı kaynaklara bakmanın yeterli olmadığını belirterek Türklerin günlük hayatta kullandıkları kelime sıklıklarına da önem verilmesi gerektiğine değinmiştir. Ayrıca Barın sıklık araştırmalarının, dildeki değişmelere göre belirli aralıklarla yapılması ve Türkçenin öğretimi ile ilgili uygulamalarda dikkate alınarak belirlenmiş olan kelimelerin kullanılmasının şart olduğunu vurgulaması kelime sıklığının araştırılması bakımından bu çalışmayla benzerlik göstermektedir.

Bu araştırmada Türkiye' de yaşayan Suriyeli genç kadın ve erkeklerin herhangi bir Türkçe kursuna gitmeden yaşayarak öğrendikleri tekrarlı kelime sayısı kadınlarda 4931, erkeklerde 3974 olmak üzere toplam 8905 kelime olduğu sonucuna varılmıştır. Kadın katılımcıların 3873 isime, 426 fiil, 350 sıfat, 81 zamir, 74 zarf ve 127 kalıp ifadeyi bildikleri sonucuna ulaşılırken erkek katılımcıların 3235 isim, 263 fiil, 193 sıfat, 75 zamir, 90 zarf ve 118 kalıp ifadeyi hafızalarına yerleştirdiklerine varılmıştır. Böylece toplam isim 7108, fiil 689, sıfat 543, zamir 156, zarf 164 ve kalıp ifadelerin 245 olduğu analiz edilmiştir. Suriyeli gençlerin Türkiye'de yaşama yıllarının dağılımı 1'den az olmak üzere 6 yıla kadar aralık göstermektedir. Araştırmaya katılan 90 kadın ve erkek katılımcının yıllara göre toplam kelime oranları şöyledir; 1 yıldan az 9 katılımcı 589 kelime, 1 yıl 14 katılımcı 1498 kelime, 2 yıl 35 katılımcı 3501 kelime, 3 yıl 12 katılımcı 1350 kelime, 4 yıl 13 katılımcı 1299 kelime, 5 yıl 6 katılımcı 534 kelime ve 6 yıl 1 katılımcı 134 kelimedir. Tekrarsız kelime sonuçlarına bakıldı̆ı̆nda ise kadın katılımcıların toplam 908 çeşitli kelime bildiklerine ulaşılırken erkek katılımcıların 817 farklı kelime bildikleri ve cinsiyet ayırmaksızın toplam kelime sayısının da 1825 olduğu sonucuna varılmıştır. Kadın ve erkek katılımcıların en çok tekrar ettikleri kelimelere bakıldığında kitap (75), kalem (72), saat (73), tahta (68), masa (67), araba (65), çanta (65), okul (62), öğrenci (62) , öğretmen (35) ve defter (34) kelimelerine rastlanmıştır. Katılımcıların en sık tekrar ettikleri 
kelimelerin eğitime ait kelimeler olması dikkat çekmektedir. Cinsiyet ayırmaksızın kategorilere göre en sık ve en az tekrar eden toplam kelime sayıları;

- Eğitim en çok, kitap (73), kalem (72), tahta (68), masa (67), çanta (65); en az pergel (4), lise (3) kütüphane (2), kırtasiye (2) ve fakülte (1),

- Aile en çok, anne (56), baba (53), kardeş (31), çocuk (18), ağabey (12), amca (12), teyze (12); en az oğul (3), akraba (2), büyükanne (1), koca (1), nine (1),

- Meslek en çok, öğretmen (59), doktor (40), polis (22), hoca (16), mühendis (16), hemşire (14); en az emekli (2), asker (2),

- Renk en çok, mavi (36), kırmızı (34), siyah (26), beyaz (25), yeşil (21); en az sarı (6) ve gri (2), kahverengi (1) ve bordo (1),

- Meyve en çok, elma (50), limon (42), üzüm (24), karpuz (22), nar (18); en az incir (4), kiraz (4), armut (2),

- İnsan vücudu en çok, göz (65), saç (46), diş (27), el (25), burun (22); en az çene (4), boğaz (3) ve kol (3),

- Hayvan en çok, köpek (49), inek (40), kedi (35), fare (29), fil (27); en az horoz (1), böcek (1), kurt (1), deve (1),

- Sayılar, en çok iki (23), yüz (23), bir (22), dört (20), üç (18); en az altmış (6), yetmiş (6),

- Toplu taşıma en çok, otobüs (34), uçak (31), metrobüs (13), gemi (11), metro (10); en az taksi (2),

- Din en çok, cami (30), bayram (14); en az peygamber (1), ramazan (1),

- Günler en çok, pazar (28), cuma (23), pazartesi (21), cumartesi (16), salı (15

- $\quad$ Fiil en çok, gelmek (34), yazmak (25), yemek (24), gitmek (22), almak (21), sevmek (21); en az geçmek (3), silmek (3), susmak (3),

- Sıfat en çok güzel (32), çok (28), iyi (20), mutlu (17), büyük (16); en az güçlü (3), korkak (3), şanslı (1),

- Zamir en çok, ben (26), sen (23), o (18), biz (17), onlar (16); en az, burası (3), şurası (3),

- Zarf en çok, akşam (22), nerede (12), sabah (12), dün (10), sonra (10); en az, nasıl (2), öğlen (2),

- Kalıp ifadeler en çok merhaba (27), nasılsın (19), evet (18), güle güle (14), hayır (14); en az teşekkür ederim (3), bol şanslar (3), tebrikler (2) olarak sonuçlandırılmıştır.

Diller İçin Avrupa Ortak Önerileri Çerçevesine bakıldı̆̆ında "Dil öğrenenler, kim olduklarını ve adını harf harf söyleyebilir, adresini, telefon numarasını, ne zaman ve nerede doğduğunu, yaşını, cinsiyetini, medeni halini ve uyruğunu söyleyebilir; nereli olduğu ve mesleği hakkında bilgi verebilir, 


\section{Suriyeli Mültecilerin Türkçe Kursuna Başlamadan Önceki Söz Varlığı Durumları}

ailesini tanitabilir, hangi din cemaatine mensup olduğunu dile getirebilir" maddesinden hareketle dil öğrenenlerin A1 seviyesinde kelime bilgisine sahip olmaları gerektiği kanısına ulaşılmaktadır (TELC, 2013). Büyükikiz ve Hasırcı' ya (2013) göre yine dil öğrenenlerin söz varlığı belirlenirken hedef kitlenin ihtiyaçları ve kelimelerin kullanılabilirliği göz önünde bulundurulmalıdır. Buna benzer bir diğer görüşte ise Barın (2003), söz varlığını belirlemek için organ ve akrabalık adlarının, sayıların ve Türklerin günlük yaşamda kullandıkları kelime sıklıklarına önem verilmesi gerektiğine değinmiştir. Arslan (2014) çalışmasında Yeni Hitit Yabancılar İçin Türkçe Seti'ni incelemiş ve A1 seviyesindeki Yeni Hitit Yabancılar İçin Türkçe kitabında toplam 5524 kelime tespit etmiştir. Göçen ve Okur (2016) çalışmalarında Gazi, Yeni Hitit ve İstanbul yabancılara Türkçe öğretimi ders kitapları setlerini incelemişlerdir. A1 Gazi Yabancılara Türkçe Öğretimi ders kitabında 1871 kelime, A1 Yeni Hitit Yabancılara Türkçe ders kitabında 2037 kelime ve A1 İstanbul Yabancılara Türkçe Öğretimi ders kitabında ise toplam 1240 kelime tespit edilmiştir. Açık (2013) araştırmasında, Yazılı Türkçenin Kelime Sıklığı Sözlüğünden faydalanarak temel seviyede öğrencilere öğretilebilecek 1369 kelime tespit etmiştir. Yapılan araştırmaların sonuçlarına bakıldığında bu araştırmaya katılan katılımcıların toplam 1825 kelime bildiği tespit edildiğinden Suriyeli gençlerin ortalama A1 seviyesindeki kelimelere hâkim olduğu ortaya çıkmaktadır. Bu sonuca göre katılımcıların Diller İçin Avrupa Ortak Önerileri Çerçevesi kapsamında kendini ve ailesini tanıtabilecek, nereli olduğunu, adresini, telefon numarasını, ne zaman nerede doğduğunu söyleyebilecek kapasitede kelime bilgisine sahip olduğu görüşüne varılmıştır.

\section{Öneriler}

Türkçenin yaygınlaşması ve bilim dili olması konusunda yabancılara Türkçe öğretiminin önemi unutulmamalıdır. Bu yönüyle Yabancılara Türkçe Öğretimi tanıtımının iyi yapııması, desteklenmesi, planlanması gereken önemli bir alandır (Ayrancı ve Temizyürek, 2017: 52). Bu planlamanın en temelinde ise ilgili alanda söz varlığı tespitlerinin yapılması gerekmektedir. Bu bağlamda Türkiye'de uzun yıllar boyunca yaşama ihtimali olan ve Türkçeyi yabancı dil olarak öğrenen Suriyeli mültecilerin söz varlığı durumlarına ilişkin yapılacakları aşağıdaki gibi sıralamak mümkündür.

Suriyeli mültecilere;

- Türkçe öğretimine başlanmadan önce ilgili öğrencilerin muhakkak söz varlı̆̆ durumları tespit edilmelidir. 
- Yönelik hazırlanan ders kitapları, sözlükler vb. materyaller ilgili söz varlığı durumları dikkate alınarak hazırlanmalıdır ve Avrupa Ortak Dil Kriterleri ile öğrencilerin söz varlığı durumlarına bakılarak her kura ait (A1, A2, B1, B2, C1, C2) "Söz Varlığı Sözlükleri" oluşturulmalıdır.

- Kurlara göre oluşturulan "Söz Varlığı Sözlükleri" incelenerek elektronik ve elektronik olmayan materyaller hazırlanmalıdır.

- Türkçe öğreten MEB, YTB, TÖMER'ler işbirliğinde Türkiye'de yaşayan fakat Türkçe öğrenmeye başlamayan bütün mültecilerin söz varlığını tespit edip bu alandaki stratejilerini bu çerçevede yeniden belirlemelidirler.

- Türkçe öğretenlere yönelik yapılan eğitim programlarında söz varlığının tespitin nasıl yapılacağı ve buna bağlı olarak derslerin nasıl şekillendirilebileceğine yönelik eğitimler verilmelidir.

- Türkçe öğretimi sürecinin başında ve sonunda olmak üzere iki kez muhakkak söz varlığı tespiti çalışmaları yapılıp Türkçe öğretiminde gelinen nokta açısından tekrar değerlendirmeler yapılmalıdır.

- Türkçe öğretiminde başarıya ulaşmak için ilgili öğrenciler ile TÖMER'lerde Türkçe öğrenenlerin söz varlığı durumları seviyelere göre karşılaştırılıp sonuçlardan hareketle kullanılacak materyallerden, verilecek ders saatlerine kadar bütün hususlar (Suriyeli öğrenciler için) tekrar gözden geçirilmelidir.

- IIlgili alanda araştırmaların sayısı artırılmakla birlikte, Suriyeli mültecilerin söz varlığı durumlarına ilişkin kapsamlı araştırmalar (yüksek lisans, doktora) yaptırılmalı veya yapılmalıdır.

\section{Kaynaklar}

Açık, F. (2013). Temel Türkçe (A1/A2) için söz dağarcığı tespit denemesi, Abdurrahman Güzel ļçin Armağan Kitabı, Akçağ Yayınları.

Aksan, D. (2000) Her yönüyle dil, ana çizgileriyle dilbilim. Ankara: Türk Dil Kurumu Yayınları.

Arslan, N. (2014). Yabancılara Türkçe öğretimi ders kitaplarında söz varlığı unsurlarının incelenmesi. Yayımlanmamış Yüksek Lisans Tezi. Karadeniz Teknik Üniversitesi Eğitim Bilimleri Enstitüsü.

Aşık, U. (2007). Yabancılar için temel Türkçe söz varlığının oluşturulması. Yayımlanmamış Yüksek Lisans Tezi. Dokuz Eylül Üniversitesi Eğitim Bilimleri Enstitüsü.

Ayrancı, Bağcı B. ve Temizyürek F. (2017). Yabancı dil olarak Türkçe öğretiminin bilim dili olarak Türkçeye katkısı. Turkish Studies, International Periodical for the Languages, Literature and History of Turkish or Turkic, Volume 12/17, p. 33-54,

Barın, E. (2003). Yabancılara Türkçenin öğretiminde temel söz varlığının önemi, TUBAR-XIII. 


\section{Suriyeli Mültecilerin Türkçe Kursuna Başlamadan Önceki Söz Varlığı Durumları}

Baş, B. (2011). Söz varlığı ile ilgili çalışmalarda kullanılacak ölçütler. Türklük Bilimi Araştırmaları 27, 27-61

Büyükikiz, K. K. ve Hasırcı, S. (2013). Yabancılara Türkçe öğretiminde sözcük öğretimi üzerine bir değerlendirme, Mustafa Kemal Üniversitesi Sosyal Bilimler Enstitüsü Dergisi, 10/21, 145-155.

Cesur, O. (2005). (Kastamonu ilinde Bir Inceleme) Pansiyonlu Ilköğretim Okulu Öğrencileri Üzerinde Kelime Serveti Araştırması. Yayımlanmamış Yüksek Lisans Tezi. Abant İzzet Baysal Üniversitesi Sosyal Bilimler Enstitüsü.

Ceylan, Ş. (2013). Ilköğretim beşinci sınıf öğrencilerinin yazı dilindeki kelime servetlerinin bazı değişkenler açısından incelenmesi. Yayımlanmamış Yüksek Lisans Tezi. Celal Bayar Üniversitesi Sosyal Bilimler Enstitüsü.

Çelik, S. (2014). Yabancı dil olarak Almanca ve Türkçe öğretimi A1 ve A2 seviyesindeki ders kitaplarında kullanılan söz varlığının karşılaştırılması. Yayımlanmamış Yüksek Lisans Tezi. Marmara Üniversitesi Eğitim Bilimleri Enstitüsü.

Çıplak, M. (2005). Uşak Merkez ilköğretim 5., 8. ve 11. sınıflarının yazılı kelime hazinesinin belirlenmesi. Yayımlanmamış Yüksek Lisans Tezi. Afyon Kocatepe Üniversitesi, Sosyal Bilimler Enstitüsü.

Demirci, S. ve Baş. B. (2016). İlkokul 3. sınıflarda söz varlığının geliştirilmesi üzerine bir eylem araştırması. Milli Eğitim Dergisi, 210,215-235.

Göçen, G. (2016) "Yabancılar İçin Hazırlanan Türkçe Ders Kitaplarındaki Söz Varlığı ile Türkçeyi Yabancı Dil Olarak Öğrenenlerin Yazılı Anlatımlarındaki Söz Varlı̆ı" Yayımlanmamış Doktora Tezi, Sakarya Üniversitesi Eğitim Bilimleri Enstitüsü.

Göçen, G. ve Okur, A. (2016). Yabancılar için Türkçe ders kitaplarındaki sözcüklerin kullanım sıklığı ve yaygınlığı. Milli Eğitim Dergisi, 210, 447-476.

İpek Eğilmez, Nigâr (2010), Illköğretim Türkçe Ders Kitaplarındaki Söz Varlığının Ilköğretim Dördüncü Sınıf Öğrencilerinin Yazılı Anlatımlarına Aktarımı. Yayımlanmamış Doktora Tezi. Uludağ Üniversitesi Sosyal Bilimler Enstitüsü.

Karadağ, Ö. (2005). Ilköğretim I. kademe öğrencilerinin kelime hazinesi üzerine bir araştırma. Yayımlanmamış Doktora Tezi. Gazi Üniversitesi Eğitim Bilimleri Enstitüsü.

Karahan, A. (2007). Uşak Ulubey ilçesi köy ilköğretim okulları 5. sınıfların yazılı anlatımlarındaki kelime servetinin belirlenmesi. Yayımlanmamış Yüksek Lisans Tezi. Afyon Kocatepe Üniversitesi Sosyal Bilimler Enstitüsü.

Keklik, S. (2016). Öğrencilerin yazılı anlatımlarındaki söz varlığını belirlemeye yönelik çalışmalarda yöntem sorunu. Milli Eğitim Dergisi, 210, 45,31-54.

Kurudayıoğlu, M. (2005). Ilköğretim II. kademe öğrencilerinin kelime hazinesi üzerine bir araştırma. Yayımlanmamış Doktora Tezi.. Gazi Üniversitesi Eğitim Bilimleri Enstitüsü.

Kurudayıoğlu, M. ve Karadağ, Ö. (2005) "Kelime Hazinesi Çalışmaları Açısından Kelime Kavramı Üzerine Bir Değerlendirme" GÜ, Gazi Eğitim Fakültesi Dergisi, C.25, S.2, s.293-307.

Pilav, S. (2008). Üniversite birinci sınıf öğrencilerinin söz varlığı üzerine bir araştırma, Yayımlanmamış Doktora Tezi. Gazi üniversitesi Eğitim Bilimleri Enstitüsü.

Serarslan, N. (2010). Konya Ereğli Atatürk ilköğretim okulu 6. sınıf öğrencilerinin kelime hazinesi üzerine bir araştırma. , Yayımlanmamış Yüksek Lisans Tezi. Selçuk Üniversitesi, Sosyal Bilimler Enstitüsü.

Şimşek, N.D. (2015). Yabancılara Türkçe öğretimi ders kitaplarındaki metinlerin ilişkisel söz varlığı açısından değerlendirilmesi, International Journal of Science Culture and Sports, 809-827.

TELC. (2013). Diller İçin Avrupa Ortak Öneriler Çerçevesi, Öğrenim, Öğretim ve Değerlendirme, Milli Eğitim Bakanlığı. 
Tülü, M. (2012). Illköğretim 5. sınıf ögrrencilerinin yazılı anlatımlarındaki aktif kelime serveti üzerine bir araştırma (Uşak/Eşme örneği). Yayımlanmamış Yüksek Lisans Tezi. Uşak Üniversitesi Sosyal Bilimler Enstitüsü.

Tüysüz, H. (2007). Gediz (Merkez) ilköğretim 8. sınıf öğrencilerinin aktif kelime servetlerinin tespiti, Yayımlanmamış Yüksek Lisans Tezi Afyon Kocatepe Üniversitesi Sosyal Bilimler Enstitüsü.

Uluçay, M. ve Börekçi, M. (2015). Ortaokul 6. sınıf öğrencilerinin yazılı anlatımlarında kullandıkları deyimler üzerine bir inceleme, Erzincan Üniversitesi Sosyal Bilimler Enstitüsü Dergisi, 9 (2), 317-338.

Yıldııım, A. ve Şimşek, H. (2013). Sosyal bilimlerde nitel araştırma yöntemleri. Ankara: Seçkin Yayıncılık.

\section{Extended Abstract \\ Introduction}

The ability of language learners to use language skills effectively in the language teaching process is directly proportional to the word they have. In this context, one of the most important aims of language teaching is to improve the vocabulary of language learners and accordingly to be able to use the target language correctly and effectively. For this reason, vocabulary is a subject that needs to be emphasized in both the native language and foreign language teaching. However, in the Turkish language as a native language, the students are related to the vocabulary (Kurudayıŏlu, 2005, Karadağ, 2005, Cesur, 2005, Çıplak, 2005, Tüysüz, 2007, Karahan, 2007, Pilav 20008, Serarslan, 2010, 2012, Ceylan, 2013; Uluçay and Börekçi, 2015; Demirci and Baş, 2016; Takıl, 2016; Dağ, 2017), the number of studies related to the vocabulary of Turkish learners as foreign languages is very small. (Şimşek, 2015, Açık 2013, Arslan 2014, Büyükikiz and Hasırcı, 2013, Çelik, 2014, Göçen and Okur, 2016, Aşık, 2007) are seen to be done in order to determine or compare the presence of the word. Within this framework, the existence of promises at basic, intermediate and high level in the teaching of Turkish to foreigners has not been fully determined. In light of this deficiency, the aim of this study is to determine the state of promise before the Syrian refugees started to teach Turkish.

Method

This research is a qualitative research designed by case study. The most basic feature of qualitative case study is the in-depth investigation of one or more cases. In other words, the factors related to a situation (environment, individual, events, processes, etc.) are investigated by a holistic approach and focused on how they affect the situation and how it is affected by the situation. In this context, the data were interpreted by content analysis method. The basic process in content analysis is to bring together and interpret similar data around specific concepts and themes (Yıldırım, Şimşek, 2013: 259). This study also found that young men and women of the Syrians came to Turkey after the Turkish word of what they just learned by living without going to any Turkish courses.

\section{Working Group}

The research study group is formed of 90 student, 49 female and 41 male who will start Turkish at Istanbul Aydın University. The easily accessible case sampling of purpose sampling methods was used in this research.

Result and Discussion

In this study, the number of repeated words learned by living without going to any Turkish courses Syrians living in Turkey, women, young men and women in 4931, has reached the conclusion that a total of 8905 men, including 3974 words. The men participants reached 3235 names, 263 verbs, 193 adjectives, 75 pronouns, 90 adverbs, and 118 mold expressions, while the woman participants reached the result of 3873 names, 426 verbs, 350 adjectives, 81 pronouns, 74 adverbs, and 127 mold expressions. Thus, it is analyzed that the total name is 7108 , verb 689, adjective 543, pronoun 156, envelope 164 and mold expressions 245 . The distribution of young Syrians living in Turkey demonstrates the range of up to 6 years for less than 1 year. The total word ratios of the 90 participating women and men participating in the survey are as follows; 1 year Less than 9 participants 589 words 1 year 14 participants 1498 words 2 years 35 participants 3501 words 3 years 12 participants 1350 words 4 years 13 participants 1299 words 5 years 6 participants 534 words and 6 years 1 participant 134 words. When the results of the irreversible words are examined, it is concluded that the total number of words of the female participants is reached to 908, while the male participants know the 817 different words and the total number of words is 1825 regardless of sex. Looking at the words that the men and women participants repeat most, the book 75 , the pen 72 , the watch 73 , the board 68 , the table 67 , the car 65 , the bag 65 , student (62), teacher (35) and notebook (34) were 
encountered. It is noteworthy that the words that the participants repeat most often are the words of education. The most frequent and least repeated total word counts by category, regardless of gender;

- The education is mostly by the book 73 , the pen 72 , the board 68 , the table 67 , the bag 65 ; at least compass (4), high school (3) library (2), stationery (2) and faculty (1),

- The family is mostly mother (56), father (53), sister (31), child (18), brother (12), uncle (12), aunt (12); at least one son (3), a relative (2), a grandmother (1), a husband (1), a grandmother (1)

- Profession is mostly of teacher (59), doctor (40), police (22), teacher (16), engineer (16), nurse (14); at least retired (2), soldier (2),

- Colors are mostly blue (36), red (34), black (26), white (25), green (21); at least yellow (6) and gray (2), brown (1) and claret red (1)

- The fruit is mostly apples (50), lemons (42), grapes (24), watermelon (22), pomegranate (18); at least figs (4), cherries (4), pears (2),

- The human body is mostly to as the eye (65), the hair (46), the tooth (27), the hand (25), the nose (22); at least the jaw (4), the throat (3) and the arm (3)

- The animal is mostly a dog (49), a cow (40), a cat (35), a mouse (29), a elephant (27); at least the cock (1), the insect (1), the wolf (1), the camel (1),

- The numbers are at mostly two (23), one hundred (23), one (22), four (20), three (18); at least sixty (6), seventy (six),

- Most of the public transport is the bus 34 , the airplane 31 , the metrobus 13 , the ship 11 , the metro 10 ; at least the taxi (2),

- Most religion is mosque (30), feast (14); at least the prophet (1), Ramazan (1),

- Days are mostly on Sunday (28), Friday (23), Monday (21), Saturday (16), Tuesday (15)

- The verb is mostly to come (34), write (25), eat (24), go (22), receive (21), love (21); at least pass (3), delete (3), silence (3),

- The adjective is most beautiful (32), very (28), good (20), happy (17), great (16); least powerful (3), coward (3), lucky (1),

- The pronoun is most pronounced, I (26), you (23), it (18), we (17), they (16); at least, here (3), there (3),

- The envelope is mostly used in the evening (22), where (12), in the morning (12), yesterday (10), then (10); at least, how (2), noon (2),

- Mold expressions are mostly hello (27), how are you (19), yes (18), goodbye (14), no (14); thank you (3), good luck (3), congratulations (2).

Looking at the frame of the European Common Prospects for Languages, "Language learners can say who they are and what their name is, letters, address, phone number, when and where they live, their age, sex, marital status and nationality; it is suggested that language learners should have vocabulary knowledge at level A1, based on the fact that they can say where they are and where they come from and can tell their profession, introduce their family (TELC, 2013). According to the results of this research it was concluded that the participants had the vocabulary to say where they can introduce themselves, their family, their address, phone number and when and where they were born within the framework of the Common European Framework of Reference for Languages. This research is important on the account of determining the properties of the target group, especially in terms of the vocabulary while Turkish education is given to Syrian refugees. 